\title{
NEZNÁMA BRONZOVÁ IHLICA Z OVČIARSKA PRI ŽILINE
}

\author{
Marián Čurný \\ DOI: https://doi.org/10.31577/szausav.2019.suppl.1.5 \\ Keywords: north-western Slovakia, Žilina Basin, Lusatian culture, Late Bronze Age, bronze pin of Malá Vieska type
}

\section{Unknown bronze pin from Ovčiarsko near Žilina}

The paper provides information on another, previously unknown, bronze pin with a spherical head and a reinforced neck from Ovčiarsko. Ovčiarsko is known for the largest depot of bronze pins of this type found by schoolchildren in 1958 and of which 13 pieces were preserved. The presented finding was provided for analysis by the finder's greatgrandson according to which it was found in the period 1918-1938 on the old road from Ovčiarsko to Žilina in the section "Hradisko", near the archaeological site - Vel'ké hradisko with a settlement of Púchov culture. Both cases of discovery, the 1958 depot and finding before 1938, there are not many relevant information about the individual finds. The method of their discovery may have several scenarios, and the multiple discoveries from one (scattered) depot can not be ruled out, nor the existence of multiple finds of the same character and age. The bronze pins from Ovčiarsko are objects from the Lusatian culture in the earlier times of the urnfields in the late bronze age, which, without distinction, belong to bronze pins of the Malá Vieska type and to the chronological stages of Br D-Ha A1.

\section{ÚVOD}

Tento krátky príspevok prináša údaje na skompletizovanie informácií o nálezoch bronzových predmetov v Žilinskej kotline. Predstavuje starší nález bronzovej ihlice z katastrálneho územia obce Ovčiarsko pri Žiline. Ovčiarsko nie je neznáme archeologickému bádaniu. Počet archeologických lokalít a nálezov z jeho chotára a jeho bezprostredného okolia do značnej miery odzrkadluje intenzitu archeologického bádania $\mathrm{v}$ tomto regióne a tiež vypovedá o charaktere niekdajšieho osídlenia. Okrem donedávna známych ojedinelých zberových nálezov so značne obmedzenou vypovedacou schopnostou sa v priebehu posledných desiatich rokov podstatne rozšírilo poznanie o osídlení Ovčiarska, a to najmä v súvislosti s realizovanými rozsiahlejšími archeologickými výskumami.

\section{OSÍDLENIE OVČIARSKA}

Osídlenie Ovčiarska v neolite potvrdzujú keramické črepy z polohy Pieskový (pravdepodobne kóta 539), ktoré boli zaevidované v Archeologickom ústave SAV v Nitre už v roku 1952. Ďalšie sporadické zberové nálezy z mladšej, resp. neskorej doby kamennej boli zistené v polohe Lány na katastrálnej hranici Ovčiarska a Bitarovej počas archeologického výskumu v predstihu výstavby dialnice D1 Hričovské Podhradie - Dubná Skala v roku 2010, ktorým sa zistilo a preskúmalo 39 sídliskových objektov z mladšej doby železnej (púchovská kultúra) a vrcholného stredoveku (12.-13. stor.; Ruttkay a i. 2015; Vojteček 2015, 180). Doterajšie vedomosti o osídlení okolia Ovčiarska v dobe laténskej a včasnom stredoveku sa viažu k susednej obci Bitarová (Budinský-Krička 1957, 456, 457; Petrovský-Šichman 1970) a nedávno sa rozšírili o nové poznatky, nálezy púchovskej kultúry z doby rímskej a vrcholnostredoveké nálezy. Tie boli zistené v polohe Lány počas archeologického výskumu v súvislosti s výstavbou dialnice D1 v roku 2014 (Čurnýl Kovár 2019, 42-48). Objavenie vrcholnostredovekého sídliska v polohe Lány časovo korešponduje s najstaršou známou písomnou zmienkou o obci Ovčiarsko, ktorá pochádza z roku 1282. Ovčiarsko je v nej doložené ako villa Olcharzk (Súpis 1968, 442). 


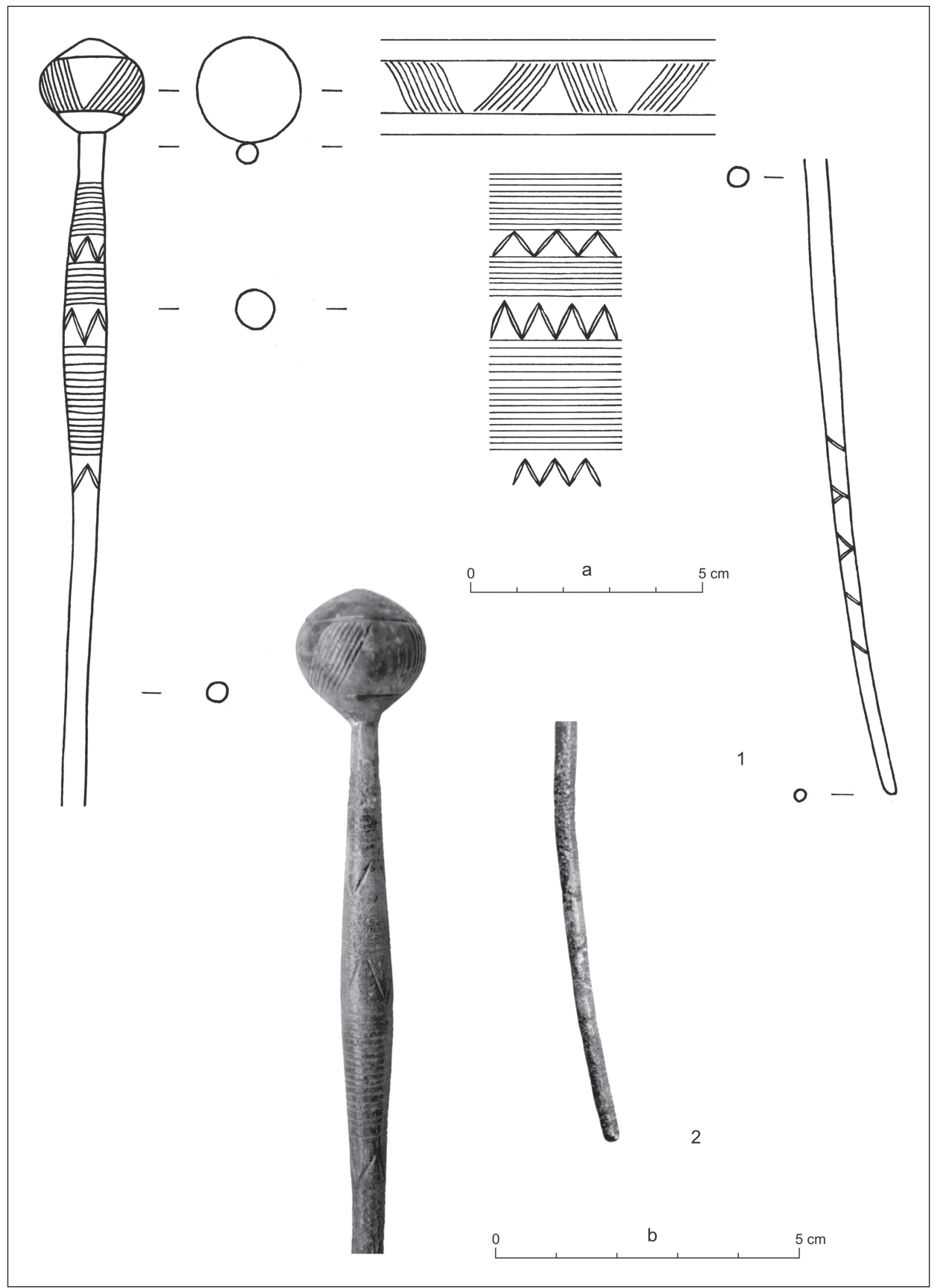

Obr. 1. Ovčiarsko, okr. Žilina. Bronzová ihlica s gul’ovitou hlavicou a zosilneným kŕčkom. Mierka: a - 1; b - 2. Kresba B. Čurná Roman, foto M. Čurný. 
V príspevku je venovaná pozornost’ osídleniu $\mathrm{v}$ dobe bronzovej. Nálezy bronzových artefaktov z tohto časového úseku sú z Ovčiarska známe z dvoch depotov. Prvý depot (depot I) z mladšej a neskorej doby bronzovej (Chebenová 2012, 6) sa dostal v závere 70. rokov 19. storočia z Ovčiarska do Národného múzea v Budapešti a podla J. Eisnera (1933, 63, 105, 106, 108, 112, obr. 4: 1, pozn. 85, 128, 133, 217) pozostával z bronzovej dýky s trojuholníkovým zakončením s otvormi pre nity, dvoch bronzových sekeriek s rôzne vyformovanými tulajkami a noža s jazykovitou rukovätou s otvormi pre nity na rukoväti a podla J. Hampla (1892, 111-113) údajne aj bronzového hrotu kopije so zdobenou tulajkou (Veliačik 2012, 329). Mladšie etapy doby bronzovej reprezentuje v tomto regióne lud lužickej kultúry, po ktorom bolo v chotári Ovčiarska objavené sídlisko a jeden žiarový hrob (Súpis 1968, 442).

V roku 1958 objavili hrajúce sa deti v jame ned’aleko bývalého kameňolomu v polohe Háj, nedaleko valu hradiska na temene svahu, ktorý rozrušil uvedený kameňolom, poklad bronzových ihlíc (depot II). Z pôvodného počtu približne 25-30 ihlíc sa rok po objave A. Petrovskému-Šichmanovi a L. Hutyrovej podarilo zachránit iba 13, ktoré sa dostali do vtedajšieho Krajského, dnes Považského múzea v Žiline. Ihlice dlhé 70-75 cm mali zosilnený kŕčok a gulovitú alebo mierne zahrotenú, či kuželovitú hlavičku. Patria do mladšej fázy strednej doby bronzovej, k lužickej kultúre (Hutyrová 1962).

\section{OKOLNOSTI NÁLEZU}

Počas archeologického výskumu, pred výstavbou dialnice D1 na úseku Hričovské Podhradie-Lietavská Lúčka v lete roku 2014, sprístupnil autorovi príspevku pracovník na výskume, Andrej Ovary z Ovčiarska, na zdokumentovanie rozmernú ihlicu, ktorú jeho rodina opatruje už niekol'ko desiatok rokov. O náleze uviedol, že ho objavil jeho prastarý otec Ondrej Plichta (20. 2. 1901-24. 12. 1981) na starej ceste medzi Ovčiarskom a Žilinou, ktorá viedla cez oblast’ dnes nazývanú „Hradisko“ a nachádza sa pri dnešnom sídlisku Hájik v Žiline. Presný dátum nálezu nie je známy, ale starý otec Andreja Ovaryho, Anton Plichta (26. 3. 1926-27. 8. 2010), svojmu vnukovi spomínal, že mu tú ihlicu jeho otec, nálezca Ondrej Plichta, ukazoval, ked' bol ešte malý chlapec. $Z$ toho sa dá usudzovał', že bola objavená približne v rokoch 1918-1938. Ihlicu opatruje rodina Andreja Ovaryho v Ovčiarsku, č. d. 93. V dobe dokumentovania nálezu v lete 2014 boli autorovi príspevku známe okolnosti nálezu depotu bronzových ihlíc z Ovčiarska z 50. rokov 20. storočia, pričom predpokladal, že pri náleze poskytnutom na zdokumentovanie ide o jeden zo stratených predmetov z depotu. S časovým odstupom sa od A. Ovaryho dozvedel informácie o okolnostiach a dobe objavenia ihlice, ktoré vylučujú jej stotožnenie s nálezom 13 známych bronzových ihlíc z depotu z Ovčiarska.

\section{Opis nálezu}

Vel'ká honosná ihlica s vel’kou gul’ovitou hlavicou a zosilneným kŕčkom (obr. 1). Zachovaná v jednom kuse, v dobrom stave, iba minimálne prehnutá približne v strede svojej dížky. Nepravidelne gul'ovitá, mierne zahrotená hlavica mala najväčší priemer $20 \mathrm{~mm}$. Cez krátky šijovitý úsek s priemerom $4 \mathrm{~mm}$ prechádzala do 60 mm vysokého zosilneného kŕčka s priemerom $8 \mathrm{~mm}$. Kŕčok plynulo pokračoval do štíhleho tela s pravidelným kruhovým profilom s priemerom $4 \mathrm{~mm}$. Koniec tela ihlice bol jednoducho zaoblený, s priemerom $2 \mathrm{~mm}$. Celková dížka ihlice bola $680 \mathrm{~mm}$. Hlavica, zosilnený kŕčok i spodná čast’ tela ihlice boli zdobené rytým ornamentom. Väčšia čast’ gulovitej plochy hlavice bola ohraničená dvomi horizontálnymi ryhami, základňami, z ktorých vychádzali diagonálne zväzky 9, 8 alebo 7 rýh. Zosilnený kŕčok bol rozdelený do troch polí vyplnených obežnými plytkými ryhami. Medzi prvým a druhým, druhým a tretím a pod tretím polom boli umiestnené šikmo lomené čiary, v porovnaní s horizontálnymi ryhami v hlbšom vyhotovení. Na spodnej časti tela, približne $70 \mathrm{~mm}$ vysokom úseku od zaobleného ukončenia ihlice, sa nachádzala slabšie čitatel’ná výzdoba zo šikmo sa krížiacich piatich hlbších rýh. Na povrchu ihlice sa nachádzala autentická zelená patina, v strednej časti tela ihlice (medzi zosilneným kŕčkom a spodnou koncovou častou) bolo zaznamenané postihnutie koróziou. Čast’ patiny na zaoblenom konci ihlice bola poškodená viacerými nehlbokými zásekmi, ktoré boli evidentne výsledkom cielenej dobovej úpravy ihlice.

\section{KULTÚRNO-CHRONOLOGICKÝ KONTEXT}

Bronzové ihlice patrili k najpoužívanejším, skoro ludovým šperkom v neskorej dobe bronzovej a halštatskej (Čaplovič 1987, 168). Charakteristické vyhotovenie výzdoby ich radí k lužickej kultúre, bežne sa 
vyskytujú i v prostredí súvekých kultúr pilinskej a kyjatickej (Furmánek 1990, 59, obr. 46). Mnohé z nálezov týchto ihlíc z oblasti lužickej kultúry pochádzajú z hromadných nálezov (napr. Bešeňová; Eisner 1933, obr. 8: 1, 4; Púchov, Ružomberok, Turčianske Teplice-Vieska, Vel'ká Lehota; Hutyrová 1962, 133), d’alšie sú známe z pohrebísk (napr. Dolný Kubín I; Čaplovič 1987, 168, obr. 17, tab. VIII: 4; Liborča, dnes Nemšová-Ĺuborča; Budinský-Krička 1947, tab. XXIV: 2; XXV: 8, 9) alebo ide o hromadné (napr. Martin-Priekopa, Turčianske Teplice; Demeterová 1977, 452, 454-456, 457), alebo ojedinelé nálezy (napr. Leštiny; Čaplovič 1987, obr. 10: 1; tab. XXV: 1), niekedy i mimo oblasti lužickej kultúry (Bodrog, Budinský-Krička 1970, 47, 48, obr. 9: 1, 4). Problematike bronzových ihlíc s gulovitou alebo dvojkónickou hlavicou a zosilneným kŕčkom sa v samostatnej štúdii venovala $S$. Demeterová (1977). Predstavila v nej súpis dovtedy známych ihlíc tohto typu zo Slovenska a datovala ich do stupňa BD/HA1 (Demeterová 1977, 458). Podla klasifikácie M. Novotnej (1980, 107-110, tab. 25-33) spadá aj doposial' nezverejnený nález bronzovej ihlice z Ovčiarska k ihliciam typu Malá Vieska, ktorý sa do svojej charakteristickej podoby vyvinul v staršej dobe popolnicových polí v mladšej dobe bronzovej a je typický pre vyššie uvedené chronologické stupne. Podobne zdobené, aj ked' spravidla subtílnejšie nálezy ihlíc s gulovitou hlavicou a zosilneným kŕčkom (typu Deinsdorf s variantmi, občas značne dlhými) zo susednej Moravy, zosystematizoval J. Říhovský (1979, 74-85, tab. 17: 310-314; 18-23).

\section{ZÁVER}

Počtom kusov doposial' najväčší depot bronzových ihlíc s gulovitou hlavicou a zosilneným kŕčkom z Ovčiarska z roku 1958 vytvára rámec, s ktorým je nevyhnutné konfrontovat aj tento doteraz neznámy ojedinelý nález. $\mathrm{V}$ oboch prípadoch je nutné konštatovat nedostatok a nekompletnost' vierohodných informácií o pôvodnej skladbe nálezu a jeho uložení. Pri náleze 13 dochovaných ihlíc v 50. rokoch minulého storočia bol ich pôvodný počet (25-30 kusov) odhadnutý. Po objavení d’alšieho kusu, ktorý zapadá do skladby tohto depotu, sa predpokladalo, že ide o jeden zo stratených predmetov. Avšak poskytnuté, no neoveritelné informácie od držitela nálezu indikujú aj iný scenár.

1. Ak platí, že k nálezu ihlice O. Plichtom došlo najneskôr niekedy v 30. rokoch 20. storočia, išlo bud' o dva samostatné nálezy rovnakého charakteru a veku, alebo o "dvojnásobné" objavenie toho istého depotu. Nemožno vylúčit ani jednu z možností. Snaha o vysvetlenie objavu „po častiach“ však môže viest’ k dohadom, či väčšia, neskôr objavená čast̉ depotu nebola svojim prvoobjavitelom spozorovaná, alebo pôvodná skladba depotu mohla byt z neznámych dôvodov roztrúsená, i ked’ je známe, že išlo o „vel'ký poklad bronzových ihlíc, ktoré boli spolu zviazané“ (Hutyrová 1962, 133).

2. Ak by informácie o dobe a mieste nálezu sprostredkované pravnukom nálezcu neplatili, dalo by sa priklonit $\mathrm{k}$ verzii, že ide o čiastočku z depotu stratenú v období medzi objavením nálezu žiakmi základnej školy a upovedomením archeológov riaditel’om školy, ktoré trvalo jeden rok (Hutyrová 1962, 133). K preukázatelnejším výsledkom o „súborovej príslušnosti“ by sa mohlo dopátrat detailnejším porovnaním predmetov z oboch nálezov.

Nález z roku 1958 sa našiel v polohe „Háj“, ned’aleko valu hradiska, na temene svahu rozrušeného kameňolomom. Presnú polohu náleziska dnes nevieme určit, no s vel'kou pravdepodobnostou asi súvisí s evidovanou archeologickou lokalitou Vel'ké hradisko na kóte 626. Nález z obdobia pred rokom 1938 sa našiel na starej ceste medzi Ovčiarskom a Žilinou vedúcej cez „Hradisko“ pri dnešnom sídlisku Hájik v Žiline. Podla opisu by mohlo íst’ o priestor južne od spomínaného Vel'kého hradiska, ktoré je zaradené do Registra nehnutelných NKP 2148/1 v katastri Žiliny, miestnej časti Závodie, pričom zo severu evidentne zasahuje aj do katastrálneho územia miestnej časti Žiliny-Strážova. Táto archeologická lokalita je evidovaná ako hradisko, refúgium, z doby laténskej a rímskej (púchovská kultúra) a uvádza sa, že je neskúmaná. Pravdepodobne k tomuto hradisku sa viažu zistovacie práce A. Petrovského-Šichmana v roku 1946, počas ktorých tu zistil črepy a hlinenú gulôčku (Petrovský-Šichman 1946). Juhozápadne od Vel'kého hradiska sa nachádza Malé hradisko, kóta 638, odkial' nie sú hlásené archeologické doklady osídlenia.

Depot a nález bronzových ihlíc v súčasnej fáze poznania nemusia nevyhnutne potvrdzovat existenciu súvekého osídlenia v oblasti Vel'kého a Malého hradiska, odkial' sú známe iba doklady osídlenia púchovskou kultúrou, no logicky ho indikujú. Ďalšou indíciou sú i dávnejšie známe, časovo trochu mladšie sídliskové nálezy z pôvodne rozsiahlejšieho sídliska z rozhrania stupňov $\mathrm{HB}$ a HC porušeného na lavom brehu Rajčianky v Žiline-Závodí v úseku medzi bitúnkovým mostom a mostom v Závodí, ktoré v roku 
1975 zachránili J. Moravčík a O. Šedo (Moravčík 1976, 157-160; 2000, 128). Lokalita sa nachádza vzdušnou čiarou iba približne $1 \mathrm{~km}$ juhovýchodne od Vel'kého hradiska.

\title{
LITERATÚRA
}

Budinský-Krička 1947

Budinský-Krička 1957

Budinský-Krička 1970

Čaplovič 1987

Čurný/Kovár 2019

Demeterová 1977

Eisner 1933

Furmánek 1990

Hampel 1892

Hutyrová 1962

Chebenová 2012

Moravčík 1976

Moravčík 2000

Novotná 1980

Petrovský-Šichman 1946

Petrouský-Šichman 1970

Ruttkay a i. 2015

Říhovský 1979

Súpis 1968

Veliačik 2012

Vojteček 2015
V. Budinský-Krička: Slovensko v dobe bronzovej a halštatskej. In: B. Varsik (red.): Slovenské dejiny. Diel I. Čast' 1. Slovensko v praveku. Bratislava 1947, 68-103.

V. Budinský-Krička: Zpráva o pokusnom výskume na slovanskom mohylníku v Bitarovej (okr. Žilina). Slovenská archeológia 5, 1957, 456-464.

V. Budinský-Krička: Bronzový depot z Bodrogu, okres Trebišov. Študijné zvesti Aú SAV 18, 1970, 25-62.

P. Čaplovič: Orava v praveku, vo včasnej dobe dejinnej a na začiatku stredoveku. Martin 1987.

M. Čurný/B. Kovár: Archeologický výskum na trase dial’nice D1, úsek Hričovské Podhradie - Lietavská Lúčka. Archeologické výskumy a nálezy na Slovensku v roku 2014, 2019, 42-48.

S. Demeterová: Nové nálezy ihlíc s gulovitou alebo dvojkónickou hlavicou a zosilneným kŕčikom zo Slovenska. Slovenská archeológia 25, 1977, 449-462.

J. Eisner: Slovensko v pravěku. Bratislava 1933.

V. Furmánek: Radzovce. Osada l’udu popolnicových polí. Bratislava 1990.

J. Hampel: A bronzkor emlékei Magyarhonban II. Budapest 1892.

L. Hutyrová: Poklad ihlíc z Ovčiarska. Vlastivedný zborník Považia 5, 1962, 133-136.

P. Chebenová: Nože z doby bronzovej na Slovensku. Slovenská archeológia 60, 2012, $1-36$.

J. Moravčík: Halštatské sídlisko v Žiline-Závodí. Archeologické výskumy a nálezy na Slovensku v roku 1975, 1976, 157-160.

J. Moravčík: Najstaršie osídlenie obcí v okolí Vodného diela Žilina od staršej doby kamennej po stredovek. Vlastivedný zborník Považia 20, 2000, 123-153.

M. Novotná: Die Nadeln in der Slowakei. Prähistorische Bronzefunde XIII/6. München 1980.

A. Petrovský-Šichman: Žilina-Strážov, Hradisko. Výskumná správa 399/46. Dokumentácia AÚ SAV. Nitra 1946. Nepublikované.

A. Petrovský-Šichman: Výskum slovanských mohylníkov v okolí Žiliny. Študijné zvesti Aú SAV 18, 1970, 193-210.

M. Ruttkay/H. Baliová/A. Nemergut/M. Vojteček/B. Zajacová: Výskumy na stavbe dial'nice D1 Hričovské Podhradie - Dubná Skala. Archeologické výskumy a nálezy na Slovensku v roku 2010, 2015, 201-203.

J. Ř́hovský: Die Nadeln in Mähren und im Ostalpengebiet (von der mittleren Bronzezeit bis zur älteren Eisenzeit). Prähistorische Bronzefunde XIII/5. München 1979.

Súpis pamiatok na Slovensku. Zväzok druhý. K - P. Bratislava 1968.

L. Veliačik: Nože z doby bronzovej na Slovensku. Slovenská archeológia 60, 2012, 285 342 .

M. Vojteček: Stredoveké dedinské sídlisko v Bitarovej. Študijné zvesti AÚ SAV 58, 2015, 169-186.

\section{Unknown bronze pin from Ovčiarsko near Žilina}

\author{
Marián Čurný
}

Summary

The contribution focuses on the unknown bronze pin from Ovčiarsko. Ovčiarsko is known for the largest depot of bronze pins of this type found by schoolchildren in 1958 and of which 13 pieces were preserved. The settlement of Ovčiarsko in the Neolithic, La Tène and Roman (the Púchov culture) and the early and high Middle Ages have 
confirmed terrain archaeological activities from the 1940's to the present. In addition to bronze pins from Ovčiarsko there are other famous finds (dagger, axes, knife and spear), which came in the $19^{\text {th }}$ century.

The presented finding was provided for analysis by the finder's great-grandson, according to which it was found originated between 1918 and 1938 on the old road between Ovčiarsko and Žilina, which led through the area now called "Hradisko" and is situated in the present-day Hájik settlement in Žilina, near the archaeological locality, Vel'ké hradisko with a settlement from the period of the Púchov culture.

The find is a lustrously decorated pin with a spherical head and reinforced neck (Fig. 1). It is preserved in one piece, in good condition, only slightly curved at approximately the middle of its length. The irregularly spherical, slightly conical head has the largest diameter of $20 \mathrm{~mm}$. Through a short, seamless section with a diameter of $4 \mathrm{~mm}$, transitions to a $60 \mathrm{~mm}$ thick, reinforced neck with a diameter of $8 \mathrm{~mm}$. The neck went smoothly into a slender body with a regular circular profile with a $4 \mathrm{~mm}$ diameter. The end of the pin body was simply rounded, with a diameter of $2 \mathrm{~mm}$. The total length of the pin was $680 \mathrm{~mm}$. The head, the reinforced neck and the lower part of the pin body were decorated with an ornament. The bulk of the spherical surface of the head was bounded by two horizontal grooves, of which were based on diagonal bundles of 9, 8 or 7 grooves. The reinforced neck was divided into three fields filled with circular shallow lines. Between the first and second, the second and third and the third field diagonally angled lines were placed, compared to the horizontal rows of deeper grooves. At the lower part of the body, approximately $70 \mathrm{~mm}$ high section from the rounded end of the pin, there was a less readable decoration from the obliquely crossing five grooves in a deeper version of the grooves. On the surface of the pin there was an authentic green patina, in the middle part of the pin body (between the reinforced neck and the lower end portion), a distortion caused by corrosion was noted. Part of the patina at the rounded end of the pin was damaged by several superficial notches, which were obviously the result of a targeted periodic adjustment of the pin. According to the conclusions of S. Demeterová $(1977,458)$ and M. Novotná (1980, 107-110, Pl. 25-33), this newly discovered bronze pin from Ovčiarsko belongs to the Malá Vieska type, which developed into its characteristic form in the earlier times of the urnfields in the late bronze Age and is typical of the Br D-Ha A1 chronological stages.

In both cases of discovery, the 1958 depot and pre-1938, there are not many relevant information about the individual finds. The way they appear may have several scenarios:

1. If the pin was indeed found before 1938, it was either two separate findings of the same character and age, or the "double" discovery of the same depot. Not one of the options can be excluded. However, attempting to explain the discovery "in parts" can lead to an understanding of the larger, later discovered part of the depot was unnoticed by the initial discoverer, or that the original structure of the depot could have been disturbed for unknown reasons, even though it is known to have been "a treasure of bronze pins, that were tied together" (Hutyrová 1962, 133).

2. If the information on the time and place of finding mediated by the great-grandson did not concur, it might be posited that it is a part of the depot lost between the discovery made by the schoolchildren of the elementary school and the call for the archaeologists by the school principal, whom surveyed the area for one year (Hutyrová 1962, 133). More provable results of "kinship" could be made by more detailed comparison of subjects from both findings.

Both finds come from the surroundings of the archaeological site Vel'ké hradisko in the land registry area of ŽilinaZávodie, which is attributed to the settlement of the Púchov culture in La Téne and Roman period, but at the same time it is stated that the area is not surveyed. In the vicinity of this locality is the Malé hradisko area, where no archaeological evidence of settlement is reported. Depot and find of bronze pins at the present state of knowledge need not necessarily confirm the existence of contiguous settlement in the area of the Vel'ké and Malé hradisko areas, but logically indicate it. Another indication is the earlier known, somewhat younger housing estates from the originally larger settlement from the Ha B and Ha C chronological stages distorted on the left bank of Rajčianka in Žilina-Závodie, which is located only $1 \mathrm{~km}$ southeast of the Vel'ké hradisko.

Fig. 1. Ovčiarsko, district Žilina. Bronze pin with spherical head and reinforced neck. Scale: a - 1; b - 2. Drawing B. Čurná Roman, photo M. Čurný.

Mgr. Marián Čurný, PhD.

Zemplínske múzeum v Michalovciach

Kostolné námestie 1

SK - 07101 Michalovce

marian.curny@gmail.com 